\title{
Development of Writing Exposition Text Materials Based-PBL
}

\author{
Rezki Islami, Syahrul Ramadhan, Yasnur Asri \\ Universitas Negeri Padang, Padang \\ rezkiislami123@gmail.com
}

\begin{abstract}
This study was conducted to overcome the limitations of teaching materials on learning exposition text of students of class $X$. This study aimed to describe the process of developing learning module of expository text based on problem based learning (PBL) that valid (in terms of content, presentation, language and graphics), effective (seen from student activities, learning outcomes, and affective students) used by grade $X$ high school students. Theories used in this study is namely exposition texts, problem-based learning (PBL), learning modules, and development models. The type of research was $R \& D$ (research \& development). The development model used was 4-D (define, design, develop, and dessiminate). The subjects of the study were students of grade X SMA N 3 Padang, amounting to 30 people.
\end{abstract}

Keywords-development; module; exposition text; $P B L$

\section{INTRODUCTION}

Writing is one of four language skills students must have. Writing skills are often accepted as the last competency that will be obtained in producing language (Hamp, 2006; Fareed, Ashraf \& Bilal., 2016). According to (Ngoh,2002) writing is a good opportunity for students to improve their skills individually. The more students practice writing, the better the students will write (Tuan, 2010).

Writing is often regarded as the most difficult language skills (Nunan, 1989). There are several obstacles faced by students in learning to write in several countries. In Vietnam, students are forced to do writing assignments in a very short period of time so that they hinder the effectiveness of their writing (Tuan, 2010). In America, students must develop executive control through repeated opportunities to write and through timely and relevant feedback (Kellogg, 2007). In North Carolina, the obstacles that hinder the writing learning process are the tendency of students who almost $50 \%$ spend time just thinking about what they want to write (Hall, 2015). In Pakistan, students' writing skills are very weak related to vocabulary treasury which makes them less fluent in writing (Dar \& Khan, 2015).

In Indonesia, writing lessons in 2013 have been replaced by text-based learning. In the 2013 curriculum it has been established that Indonesian language is considered to be an advocate of all text-based learning. Mahsun (2014, p.3) states that the text is a unit of language that is used as an expression of a social activity both orally and in writing with a complete thinking structure Text-based terms according to Sufanti (2013) are the lessons that make the text the foundation, principle, base and pedestal. This is because the text is a complete expression of the human mind in which it has a situation and context. Each text has its own structure that is different from one another.

One of the types of texts that high school X students should study in the odd semester of the 2013 curriculum is the exposition text. Exposition texts are a type of text that serves to express an idea or suggest something based on strong argumentation (Kemendikbud, 2013, p. 195). Mahsun (2014, p. 31) suggests that the expository text is a text that contains the exposure of ideas or suggestions of something that is personal. This text is for the reader to get information and knowledge very clearly. Exposition texts are usually furnished with expert opinions, examples, and facts (Kosasih, 2013, p. 40).

Exposition writing skills for high school (SMA) are in KI 4 and KD 4.4. KI 4, "Processing, reasoning, and presenting in the realm of concrete and abstract realm related to the development of the self-study in the school independently, and capable of using the method according to the scientific rules." KD 4.4, "Contextualizing the text of the exposition by taking into account the content (problem, argument, knowledge, and language) ".

Field facts indicate that there is still a problem in writing the expositions of students. The problems are as follows. First, the limitations of learning resources. Second, teachers still dominate when learning process. Third, learning is based on an incomplete package. Fourth, students are less interested in writing exposition texts. Fifth, the students' knowledge of the exposition text is minimal, especially in the parts of the elements and structures contained in an exposition text, so that students experience difficulties in producing exposition texts.

Based on the above explanation, the fundamental thing that causes problems in the activities of writing exposition text is the limited learning resources used by students. Learning resources used by students in teaching and learning process only one of the books published by the latest revision Kemendikbud. In the book the details of the concept of expository text learning materials are in accordance with the demands of the curriculum, but the exposure of learning materials within the source of learning is still a little incomplete. To overcome this then one alternative or solution that can be done is to develop a source of learning that can be used to support the use of the main book, one of 
which is the source of learning made by the teacher. Learning resources in question is the module of writing exposition text.

The module is an independent learning package that includes a series of learning experiences that contain goals, the process of learning activities that allow students to obtain competencies that have not been mastered (Mulyasa, 2006). The module was developed because it has many advantages (Syahrul, 2015).In addition the module is also useful to support existing teaching materials, to provide opportunities for students to learn independently with the concept described in the module, and can improve student competence (Yulastri, 2017).

The learning module of writing exposition texts was developed based on problem based learning (PBL). The concept of PBL is in line with a scientific approach and text-based learning. Ibrahim (2000) mentions that problembased learning involves students in learning information in the same way when recalling and applying in future situations and assessing learning by demonstrating understanding rather than mere skill. PBL also encourages students to be more active than traditional learning methods (Graaff, 2003, p 657).

Tik (2014) said that designing PBL problems is a critical step because PBL is built around the problem. Hung (2013) said PBL can improve student learning outcomes. White (2011), emphasizes the role of instructors in PBL, demonstrating that they are classroom environments where students "receive systematic instruction in conceptual, strategic, and reflective reasoning in the context of discipline that will ultimately make them more successful in later investigations".

Based on the background, this study aims to describe the process of developing learning module based on learning problem based learning (PBL) on expository text writing material to improve students' valid learning outcomes (in terms of content, presentation, happiness, and kegrafikan), practical (in terms of ease of use and conformity with time), and effective (seen from the results of student learning and activity) for students of grade X high school.

\section{METHODS}

The type of research used in this study is research development (research and devolopment). According to Arikunto (2008, p.6) research development is activities undertaking a particular product and reviewing the effectiveness of the product. Meanwhile, according to Sugiyono (2010, p. 407) research and development method is a research method used to produce a particular product, and test the effectiveness of the product. From that opinion it can be concluded that the development research is the activity of conducting experiment and refinement.

This development research uses 4-D models (four-D models) proposed by Thiagarajan, et al (in Trianto, 2012, p. 93). The development process is done by 4 stages, namely (a) define, b) design, c) development, and (d) disseminate, but resist disseminate is not done because it takes time old and requires a large sample. The type of data in this study mix between quantitative data and qualitative data. Data were obtained through questionnaires, interviews, observation sheets, and tests. Data analysis techniques used are descriptive data analysis and use descriptive statistics to obtain data validity, practicality, and module effectiveness.

Tests conducted in SMA Negeri 3 Padang. The number of research subjects were 30 students consisting of 16 male students and 14 female students. The selection of the school was the subject of trials on the grounds that the school has been using the 2013 revised edition of Curriculum 2017.

\section{FINDING AND DISCUSSION}

This development research produces a product in the form of learning module based on prbolem based learning (PBL) for grade X SMA / MA students. This module is titled Skillfully Writing Exposition Text. The module design is developed in accordance with the module-making structure that is integrated with the problem-based approach (PBL).

This learning module is expected to help students skillfully write expository text according to structure, linguistic characteristic, and social function contained in an exposition text either independently or group. Thus, learning does not only make the teacher as a learning center but also students who play an active role in teaching and learning process.

The exposition writing skills module is developed using the 4-D (Four-D) development model, which consists of four stages: define, design, develop and disseminate.

\section{Define Stage}

This research begins with a define stage or a defining stage. The definition stage is an early stage in module development. This defining stage aims to define and define the requirements necessary to construct a product to be developed (Thiagarajan, 1974, p.6). At this stage, the determination of learning requirements by analyzing the basic competencies and learning materials based on the 2013 curriculum.

The results for the define stage are described below. First, the final preliminary analysis. This data analysis is obtained from interviews conducted with Indonesian language teachers in SMA N 3 Padang. The results of these initial analyzes can be seen as follows. 
Table 1. Preliminary Analysis

\begin{tabular}{|c|c|c|}
\hline No. & Question & Answer \\
\hline 1. & $\begin{array}{l}\text { What curriculum is used in Indonesian language } \\
\text { learning in SMA? }\end{array}$ & Curriculum 2013 \\
\hline 2. & Since what year does the curriculum use? & Since 2013 \\
\hline 3. & $\begin{array}{l}\text { In learning writing expository texts, are students } \\
\text { active in learning? }\end{array}$ & Active, but not all students \\
\hline 4. & $\begin{array}{l}\text { Is the learning of writing expository texts } \\
\text { dominated by teachers or students? }\end{array}$ & Nothing dominates, between teachers and students alike. \\
\hline 5. & $\begin{array}{l}\text { What are the constraints in learning to write } \\
\text { expository texts? What learning resources are used } \\
\text { in learning to write expository texts? Does it use } \\
\text { books, LKS, or also use modules? }\end{array}$ & $\begin{array}{l}\text { Constraints in writing exposition texts may be a limitation } \\
\text { of teaching materials. Books of teachers and student books } \\
\text { issued by the government. There is no. }\end{array}$ \\
\hline 6. & $\begin{array}{l}\text { What is the student's ability in writing exposition } \\
\text { texts? }\end{array}$ & Not bad \\
\hline 7. & What is KKM for Indonesian language learning? & 80 \\
\hline 8. & $\begin{array}{l}\text { What are the common mistakes in expository texts } \\
\text { written by students? }\end{array}$ & $\begin{array}{l}\text { Often write exposed or incomplete expository text } \\
\text { structure. }\end{array}$ \\
\hline 9. & $\begin{array}{l}\text { At the time of learning process writing exposition } \\
\text { text is there any use of learning method? If so, } \\
\text { what is the original method? }\end{array}$ & Scientific approach \\
\hline 10. & $\begin{array}{l}\text { Is the learning process of writing an exposition } \\
\text { ever using Problem Based Learning? If ever, what } \\
\text { products are produced? }\end{array}$ & Never done on learning exposition text. \\
\hline 11. & $\begin{array}{l}\text { What is the attitude of students in learning to write } \\
\text { exposition text? }\end{array}$ & Students' attitudes are good, but not all \\
\hline 12. & What are the assessments of attitudes assessed? & $\begin{array}{l}\text { Assessment of attitudes by format from } \\
\text { Kemendikbud. }\end{array}$ \\
\hline 13. & Are regular attitude assessments performed? & No \\
\hline 14. & $\begin{array}{l}\text { In the process of learning to write expository texts, } \\
\text { are the students trying to do it themselves, or have } \\
\text { some copied, or often copied? }\end{array}$ & $\begin{array}{l}\text { Diverse, but thoroughly students } \\
\text { both in doing the task. }\end{array}$ \\
\hline 15. & $\begin{array}{l}\text { In terms of time, how students' ability to work } \\
\text { with time management aimed at a set time? }\end{array}$ & $\begin{array}{l}\text { There are still many students who continue } \\
\text { complete the task at home. }\end{array}$ \\
\hline 16. & $\begin{array}{l}\text { How do students do and complete tasks in earnest } \\
\text { and on time? }\end{array}$ & $\begin{array}{l}\text { To be on time is difficult, because of time } \\
\text { short learning. }\end{array}$ \\
\hline
\end{tabular}

Based on these early analyzes it can be concluded that teachers need additional learning resources to support the main learning resources in learning to write expository texts.

Second, student analysis. Student analysis aims to determine the initial behavior and characteristics of students who became the subject of research. Based on the analysis of students who have done, there are two aspects that are analyzed namely the analysis of characteristics and skills of students. Analysis of the characteristics of students is done to identify the gender, age, and maturity level of grade X students MIPA 5 SMA Negeri 3 Padang. Analysis of student skills is done to know the students' understanding and writing skills.

According to Piaget's cognitive theory, human cognitive development consists of four stages: motor sensory period (0-2 years), preoperational (2-7 years), concrete operational (7-11 years), and formal operational (11-15 years). Students aged 11 years and over, generally already able to think in a more logical way. That is, students are able to solve problems and test the possibility of solutions in a systematic and organized way.

Students who made the trial class aged 15-16 years. Students in the 15-16 age group are in the formal operational period. That is, students are able to think logically, that is able to think carefully and in accordance with common sense. Then, students are able to think abstractly. Students are able to create and assemble concepts in their minds so as to find and formulate something analytically (Mulyaningsih, 2011). 
Third, curriculum analysis. Based on the analysis, the curriculum used is the revised 2013 curriculum in 2016. For the writing study, the core competencies contained in the curriculum are the core competency-4, while the Basic Competency in learning to write debate text is in KD 4.4.

Fourth, concept analysis. Based on concept analysis, there are three aspects found. (1) The main concept of learning materials writing exposition texts has been in accordance with the applicable curriculum. This is because the source of learning used by students is a book published by Kemendikbud. (2) Details of the concept of learning materials writing exposition texts. Details of the concept of debate text learning materials are in accordance with the demands of the curriculum, developed based on text-based learning. The concept of learning to write expository texts is the notion of expository texts, the structure of exposition texts, the features of expository text, the function of exposition texts, and the steps of writing exposition texts. (3) Exposure of learning materials in learning resources. For the understanding of expository text in student learning resources is shown in abstract. The elements of the exposition text as well as the structure of the expository text builder are not explained theoretically, but are explained by example and tasks. While explanations of the social function of the exposition text in the textbook do not exist. Similarly, the steps of writing expository texts are not spelled out in the package book.

\section{Stage Design}

The design of the module structure is developed in accordance with the opinion expressed by Daryanto and Aris (2014, p. 293), which consists of three main parts, namely introduction, learning and evaluation. However, before that section, there will be a cover page, introduction, table of contents, module position map. Then, at the end of the module is a list of referrals and author notes.

The module structure designed in this research is as follows. The introductory section contains KI and KD (formulated according to Curriculum 2013), prerequisites, orientation, timing, and module usage instructions. Prerequisites contain the initial knowledge or ability students must possess to study the modules. Then, the instructions for using the module include guidelines or module use arrangements, which include instructions for using the module for teachers and students, as well as instructions on using the time to learn modules.

Furthermore, the learning activities section includes indicators of achievement of competencies, objectives of learning activities, material descriptions, summaries, assignments, tests, and worksheets. Part of learning activities is divided into two, namely learning activities 1 for aspects of knowledge and learning activities 2 for aspects of skills. Learning activities in the module are integrated with problem based learning approach. Students are faced with issues close to the world of students and issues that are becoming public conversations. Students learn to address the given problem, so that students skillfully argue in expository texts and are skilled at writing exposition texts. This is what distinguishes this learning module with other modules.

\section{Development Stage and Phase Desseminate}

Development stage is a stage that is done after the design and development phase is completed. This stage is done to test the draft module that has been designed. Based on the draft that is designed can be known three things namely the validity, practicality, and effectiveness. Validity is a module feasibility test. Practicality is a test of the practicality of using modules. This test is obtained through a dispersed questionnaire containing the ease and efficiency of the time obtained when using the module. Effectiveness is a module effectiveness test designed. The test was obtained based on cognitive tests, and psychomotor tests after the students used the designed modules. In addition, effectiveness can also be seen based on the attitude assessment during the use of modules.

Before experimenting with the designed module, especially done by experts. This is done to get a qualified module and feasible to use in learning. Validation is important to get an assessment of draft modules that have been prepared. This is in accordance with the opinion of Emzir (2010, p. 273) which states that the validation process is a product design assessment conducted by providing an assessment based on rational thinking. Results validity can be seen in the following table.

Table 2. Results Module Validation By Expert

\begin{tabular}{cccc}
\hline No. & Rated Aspect & Validity (\%) & Value \\
\hline 1. & Eligibility of Content & 87,5 & Very Valid \\
\hline 2. & Eligibility of Language & 79,2 & Valid \\
\hline 3. & Eligibility of Presentation & 67,5 & Valid \\
\hline 4. & Eligibility of Display & 75 & Valid \\
\hline & Module Validation Entirely & 76,87 & Valid \\
\hline
\end{tabular}

After validity test and module are designed categorized valid, then the module is tested to get the value of practicality and effectiveness. The experiment in question is teaching a validated material that has been validated to some sample people. The practicality test is performed after the module is used by the student. The results of 
practicality are obtained from the questionnaire of practicality filled by teachers, questionnaires practiced by students, and learning activities. The value of such practicability is described as follows.

First, the practice of teachers. the value of this practice is obtained through the questionnaire by the teacher. The results of the teacher's practicality can be seen in the following table.

Table 3. Results of Practical Value by Teachers

\begin{tabular}{|c|c|c|c|}
\hline No. & Rated Aspect & Value of Practicality (\%) & Value \\
\hline 1. & The Ease of Using & 94,64 & Very Practical \\
\hline & Time Used & 91,67 & Very Practical \\
\hline$\overline{\mathrm{Moc}}$ & le Parctical Entirely & 94,12 & Very Practical \\
\hline
\end{tabular}

Second, the students practice. the value of this practicality is obtained through the questionnaire by the students. The results of the student's practicality can be seen in the following table.

Table 4. Results of Practical Value by Students

\begin{tabular}{llcc}
\hline No. & \multicolumn{1}{c}{ Rated Aspect } & Value of Practicality (\%) & Value \\
\hline 1. & The Ease of Using & 90,26 & Very Practical \\
\hline 2. & Time Used & 90,28 & Very Practical \\
\hline \multicolumn{2}{l}{ Module Parctical Entirely } & 90,27 & Very Practical \\
\hline
\end{tabular}

Third, the effectiveness of learning modules can be seen from the attitudes (affective), the value of knowledge (cognitive), and the value of skills (psychomotor). The value of effectiveness can be seen in the following table.

Table 5. Results Evaluation value of learning

\begin{tabular}{llll}
\hline No. & \multicolumn{1}{c}{ Assessment } & Value & Predicate \\
\hline 1. & Attitude (Affective) & 92,59 & A \\
\hline 2. & Knowledge (Cognitive) & 87,96 & A \\
\hline 3. & Skills (Psychomotor) & 86,52 & A \\
\hline
\end{tabular}

Next, the disseminate stage. Learning modules that have been valid, practical and effective are disseminated to Indonesian language teachers in research schools, libraries in research schools, and distributed to Indonesian language teachers in West Sumatra who are students of the Department of Letters and Letters of Indonesia at Universitas Negeri Padang.

\section{CONCLUSION}

Based on the results of the development that has been done, it can be concluded the following points. First, the module development process that has been done includes four stages, namely define, design, development, and disseminate. This development process produces the product of learning module of expository text based on problem based learning (PBL valid, practical, and effective).

Second, the module development process at the define stage. At this stage it is concluded that there are some problems that hamper the achievement of the objective of writing expository text, ie the limitations of teaching materials used. This has an impact on student learning outcomes that still have an average under the Minimum Passing Criteria (KKM). ). Therefore, it was designed one of the learning materials in the form of learning module of expository text based problem based learning (PBL) as one solution to solve the problem.

Third, the module development process at the design stage. At this stage the module framework is designed and drafting the module. The planning of the learning module framework consists at least of instruction manual, competence to be achieved, material content, exercises, and worksheets. Components are organized into three parts, namely the introduction, learning, and evaluation. At the drafting stage of the module, a module of learning is made based on the module framework.

Fourth, the module development process at the development stage (develop). At this stage, the module that has been created is further validated to see the validity of the module. The learning module of expository text based problem based learning (PBL) developed categorically is very valid. The validity of the module is illustrated by the validation by the expert on the four aspects of module validation, namely the content feasibility aspect, the language, the presentation, and the graphics. 
Fifth, the process of developing the module at the dissemination stage (disseminate). Stage of the module deployment is done three stages. (1) Distribution to teachers other than teacher research collaborators in SMA N 3 Padang. The teacher is an Indonesian teacher who teaches class X. (2) Dissemination to the students by submitting the learning module to the school library, namely SMA N 3 Padang library. (3) Spreading to friends. Distribution is also done with Indonesian teachers who continue their education at the Graduate School of UNP majoring in Language Education and Indonesian Literature.

\section{References}

Arikunto, S. dan Jabar, C. S. (2008). Evaluasi Program Pendidikan Pedoman Teoritis Praktis bagi Mahasiswa dan Praktis Pendidikan. Jakarta. Bumi Aksara.

Dar, M. F., \& Khan, I. (2015). Writing Anxiety Among Public and Private Sectors Pakistani Undergraduate University Students. Pakistan Journal of Gender Studies, 10 (1), 121- 136. Unduh tanggal 9 Juni 2018.

Daryanto and Aris. (2014). Development of learning tools (Syllabus, RPP, PHB, Instructional Materials). Gava Media: Yogyakarta.

De Graaff, E and Kolmos, A (2003). Characteristics of Problem-Based Learning.International Journal Enginering Education. Vol 9. No 5. pp 657- 662. Unduh tanggal 19 Juni 2016.

Emzir. (2010). Educational research methodologies: qualitative and strongitative. Jakarta: Raja Grafindo Persada.

Fareed, Ashraf \& Bilal. (2016). Learners' Writing Skills: Problems, Factors and Suggestions. Journal of Education and Social Sciences Vol. 4(2): 1, 2016 ESL. Unduh Tanggal 9 Juli 2018.

Hall. (2015). Examining the Effects of Preschool Writing Instruction on Emergent Literacy Skills: Early Childhood Education Journal, 42(6), 423-430. Unduh tanggal 9 Juli 2018.

Hamp-Lyons, L. \& Heasly, B. (2006). Study Writing (2nd Ed.). Cambridge: Cambridge University Press.

Ibrahim, M., dan Nur, M. (2000). Pengajaran Berdasarkan Masalah. Surabaya:University Press.

Kellogg. (2007). Improving the writing skills of college students. Journal Psychonomic Society. Volume 14 . Issue 2. Page 237-242. Unduh tanggal 9 Juni 2018.

Kemendikbud. (2013). Permendikbud No. 66 Tahun 2013 tentang Standar Penilaian. Kurikulum. Jakarta: Menteri Pendidikan dan Kebudayaan Indonesia.

Kosasih, E. (2013). Kreatif Berbahasa Indonesia. Jakarta: Erlangga.

Mahsun. (2014). Teks dalam Pembelajaran bahasa Indonesia Kurikulum2013.Jakarta: Rajawali Press.

Mulyaningsih, E. (2011). Analisis model-model pendidikan karakter untuk usia anak-anak, remaja, dan dewasa. https://scholar.google.com/scholar (Diunduh 10 September).

Mulyasa. (2006). Kurikulum yang disempurnakan: Pengembangan Standar Kompetensi dan Kompetensi Dasar. Bandung: Remaja Rosda Karya.

Ngoh, T.J. (2002). From Journals to Weekly Papers. Guidelines. Volume. 24, June 2002.

Nunan, D. (1999). Second English Teaching and Learning. Boston: Heinle \& Heinle Publishers.

Sufanti, M. (2013). Pembelajaran bahasa indonesia berbasis teks: belajar dari ohio amerika serikat. Artikel. Unduh 27 Juli 2017.

Sugiyono. (2010). Metode penelitian pendidikan pendekatan kuantitatif, kualitatif, dan r \& d. Bandung: Alfabeta.

Syahrul. (2015). Pengembangan Modul Pembelajaran Bahasa Indonesia Berbantu Peta Pikiran Pada Materi Menulis Makalah Siswa Kelas XI SMA/MA. Jurnal Scholar. Untuh tanggal 18 Agustus 2018.

Thiagarajan, S., et al. (1974). Instructional developmen for training teacher of exceptinal children: a sourcebook: Indiana: Indiana University.

Tik, C. C. (2014). Problems Implementing Problem-Based Learning by a Private Malaysian University.Journal of Problem Based Learning in Higher Education, 2(1), hal 11-17.

Tuan. (2010). Pengajaran bahasa inggris. Jurnal Luu Trong Tuan National University of Ho Chi Minh City. Vol 3 no 3 september 2010 .

White, H. (2011). Problem-based Learning. Stanford University Newsletter on Teaching: Speaking of Teaching. Unduh tanggal 19 Juli 2016.

Yulastri, A., Hidayat, H., Ganefri, Islami, S., Edya, F.(2017). Developing an entrepreneurship module by using productbased learning approach in vocational education.International Journal of Environmental \& Science Education. 12(5), 1097-1109. 